configuration, and the cubic surface have left a permanent mark on the subject. In algebra he contributed to the theory of canonical forms of ternary and quaternary quantics. In analysis he was an authority on elliptic functions, his book on this subject being an original and elegant introduction to the general theory; and he contributed also on various other topics, touching even on the calculus of variations. But the problem which gave direction and stimulus to his best work in later years was that of the rectangular plate, which led him far into pioneering work on integral equations. This problem, as to the deflection produced at any point of a thin rectangular plate, clamped round the edges, by a load concentrated at one point of the plate, was brought to his notice by the professor of engineering at Belfast; and in it Dixon found an elusive and tantalising quest, after his own heart, and one which led him further afield into researches, of no immediate interest, it is true, to the engineer, but of great interest indeed to the pure mathematician. It was this problem, the partial progress made, and the methods which might lead to a complete solution, which formed the subject of his presidential address to the London Mathematical Society in 1933.

In the field of mathematical problems and recreations, also, Dixon contributed to the famous fifteen school-girls problem and to the problem of colouring a map ; and at the end of last century he was setting, in entrance scholarship papers in Galway, 'shadow' division sums of the type that attained such widespread popularity later as mathematical conundrums.

As a teacher, Dixon was particularly invaluable to his advanced students on account of the breadth of his knowledge, and because he had the unusual gift of having it all ready to hand all the time-he never seemed to get 'rusty' on any branch he had ever studied. On the other hand, he never gave one the impression of great erudition; he seemed indeed, on the contrary, to prefer to trust to his own amazing resourcefulness in attacking any problem rather than spend a long period in gaining a comprehensive knowledge of all the contributions of others to its solution. His lectures were models of conciseness and economy of effort; and the quiet and imperturbable way in which he delivered them caused him to be known among his students at one period as 'the leisurely professor'. Even the weakest of his students, however, though he might find Dixon's lectures very hard going, always instinctively recognised and respected his greatness as a scholar and a man.

Science has lost in Dixon an eminent mathe. matician, who has justly been described as one of the last, if not the very last, of the great 'all-rounders'; and his many pupils and former colleagues will greatly mourn the loss of a stimulating teacher and a loyal friend.

J. G.S.

\section{Mr. J. Whitehead, K.C.}

THE death of Mr. James Whitehead, K.C., on April 3, has removed an outstanding figure among those whose work lay in the exposition of scientific matters. He had for many years occupied a predominating position in technical cases which came before the Law Courts, and was engaged in numerous actions where complicated scientific phenomena have had to be explained to tribunals little conversant with such matters. For this work he had peculiar and striking gifts. He was able to make difficult and unfamiliar scientific ideas not only intelligible but also even fascinating, and it was this faculty which contributed largely to his success at the Bar.

Mr. Whitehead was, however, in addition, by reason of his eritical and logical mind, a skilledthough always a quiet and courteous-cross-examiner of scientific witnesses. As a man he was distinguished by his courage and kindliness and by his wide sympathies and interests. In spite of the exacting character of a heavy practice he was always willing to place his knowledge and experience at the service of the public, particularly in relation to education in science and in the law, notwithstanding the fact that for many years he had to carry on his work under the burden of indifferent health.

James Whitehead was the eldest son of J. R. Whitehead, of Padiham, Burnley. He entered the Royal College of Science with a scholarship in October 1896, and in June 1899 became an associate of the Royal College of Science in chemistry. After a period of a year as student demonstrator in the Chemistry Department of the College, he became science master at Berkhamsted School, which position he held until the year 1911. He was called to the Bar in 1910 and began active practice in 1911. He took silk in 1923 and was elected a bencher of Gray's Inn in 1924 .

Outside his chosen profession, Mr. Whitehead's activities were numerous. $\mathrm{He}$ was one of the first nine fellows of the Imperial College of Science elected in 1932, was a member of the governing body of the College for some years, and was a representative of the legal profession on the senate of the University of London. He served as a member of the Board of Trade Committee on the amendment of the Patents and Designs Act under the chairmanship of Sir Charles Sargent, and took a prominent part in the proceedings of the International Association for the Protection of Industrial Property, and was chairman of the British group when the International Conference of that body was held in London. In December of last year he became chairman of a committee of investigation into the milk trade under the Agricultural Marketing Act in succession to the late Mr. Edward Shortt, K.C. This inquiry con. tinued until February of this year, and he had barely completed the report on the inquiry when he was stricken with the illness which in a few days caused his death.

Mr. Whitehead leaves behind him to his many friends both in the legal profession and in the scientific world the memory of a man of rare char. acter and intellectual ability, and of a kindly, generous nature, whose wide sympathies and eager enthusiasm for, and knowledge of, many diverse subjects rendered him a most interesting and delightful companion. 